\title{
Identical Structural and Receptor Binding Defects in Apolipoprotein E2 in Hypo-, Normo-, and Hypercholesterolemic Dysbetalipoproteinemia
}

\author{
Stanley C. Rall, Jr., Karl H. Weiscraber, Thomas L. Innerarity, and \\ RoBert W. MAHLEY, The Gladstone Foundation Laboratories for \\ Cardiovascular Disease, Cardiovascular Research Institute, Departments of \\ Pathology and Medicine, University of California, San Francisco, \\ San Francisco, California 94140
}

\author{
GERD ASSMANn, Zentrallaboratorium der Medizinischen Einrichtungen der \\ Westfälischen Wilhelms-Universität, Münster, West Germany
}

A B S T R A C T Apolipoprotein E (apoprotein E or apoE) from type III hyperlipoproteinemic subjects with the E2/2 homozygous phenotype displays both structural and receptor binding heterogeneity. The apo- $\mathrm{E}$ from all subjects thus far studied, however, has been functionally defective, though to different degrees. Although nearly every type III hyperlipoproteinemic subject has the $\mathrm{E2} / 2$ phenotype, $95-99 \%$ of the people with this same phenotype do not display type III hyperlipoproteinemia, nor do they have elevated plasma cholesterol levels. Consequently, it became important to determine whether the apo-E2 from hypo- and normocholesterolemic individuals with the $\mathrm{E} 2 / 2$ phenotype is also functionally abnormal. To do this, apo-E2 was isolated from two hypo-, two normo-, and two hypercholesterolemic homozygous $\mathrm{E} 2 / 2$ subjects. The apo-E2 was recombined with phospholipid vesicles and tested for its ability to displace ${ }^{125}$ I-low density lipoproteins (LDL) from apo-B,E (LDL) receptors on human fibroblasts. The apo-E2 from all six subjects $w$ as found to be severely defective in receptor binding ( $<2 \%$ of the binding activity of normal apo-E3). In all cases, the binding activity of the apo-E2 was increased 10- to 20-fold by treating the apoproteins with cysteamine, a reagent that converts cysteine residues to positively charged lysine analogues. The cysteine content of each apo-E was determined by monitoring the

Address correspondence to Dr. Mahley.

Received for publication 22 October 1982. change in the isoelectric focusing position of the cysteamine-treated apo-E2. Using this method, it was found that the apo-E2 from each subject contained two cysteine residues per mole. A partial sequence analysis of the cysteine-containing regions of the apoE from three of the six subjects indicated that the two cysteine residues were at residues 112 and 158 in the amino acid sequence. The cysteine at residue 158 has previously been implicated in the severe binding defect of the apo-E2 from a type III hyperlipoproteinemic subject. Since the apo-E2 of the hypo-, normo-, and hypercholesterolemic subjects in this study all displayed a severe functional abnormality, it is apparent that factors in addition to the defective receptor binding activity of the apo-E2 are necessary for the manifestation of type III hyperlipoproteinemia.

\section{INTRODUCTION}

The complex isoform pattern displayed by human apolipoprotein $\mathrm{E}$ (apoprotein $\mathrm{E}$ or apo-E) ${ }^{\prime}$ is due to primary structural differences and posttranslational modification. Utermann and his colleagues (1-3) were the first to demonstrate the genetic polymorphism of the apo-E isoforms. Since then, evidence has been presented to show that this genetic polymorphism results from the presence of multiple alleles at a single genetic

\footnotetext{
'Abbreciations used in this paper: apo, apolipoprotein DMPC. dimyristoylphosphatidy.lcholine.
} 
locus and the posttranslational sialylation of apo- $\mathrm{E}$ (4 5). Recently, we found that the genetically determined, major (unsialylated) isoforms of apo-E (E2, E3, and E4) differ from one another in primary structure $(6,7)$. This indicates that the genetic control is at the level of the structural gene for apo- $\mathrm{E}$ and confirms the prediction of the Zannis-Breslow hypothesis $(4,5)$.

Utermann et al. (8) demonstrated that a specific apo$\mathrm{E}$ phenotype is associated with the lipid disorder type III hyperlipoproteinemia (primary dysbetalipoproteinemia), an observation confirmed by others $(9,10)$. Individuals with this disorder are homozygous for E2 (8) and have a hyperlipoproteinemia characterized by the accumulation of apo-E-enriched chylomicron and very low density lipoproteins (VLDL) remnants (of both hepatic and intestinal origin) in the plasma (11). Because apo-E appears to be responsible for the receptor-mediated uptake of remnant lipoproteins by the liver (12-16), and the mutant form of apo-E (E2) interacts poorly with lipoprotein receptors $(17,18)$, it is likely that this mutant apo-E2 is responsible for the defective lipoprotein clearance in type III hyperlipoproteinemic subjects and the resulting dyslipoproteinemia in certain patients $(13,17-19)$.

Population studies $(1,2,5)$ have revealed a much higher frequency of the E2/2 homozygous phenotype $(\sim 1 \%)$ than would be expected from a specific association with type III hyperlipoproteinemia, which occurs in $\sim 0.01-0.04 \%$ of the population (20). It has been found that most individuals homozygous for this phenotype display varying signs of dyslipoproteinemia without having the other clinical symptoms of the type III disorder, which is characterized by grossly elevated levels of plasma cholesterol and triglycerides, the presence of abnormal lipoproteins (the cholesteryl esterrich, $\beta$-migrating VLDL $[\beta$-VLDL]), the occurrence of planar and tuberous xanthomas, and an increased risk of premature atherosclerosis $(1,2,21,22) .^{2} \mathrm{Ob}$ servations from kindred studies have led to the suggestion that factors in addition to E2 homozygosity (the E2/2 phenotype), such as independently heritable hyperlipidemias, are necessary for the expression of type III hyperlipoproteinemia $(2,23)$.

In light of recent findings that apo-E from different type III hyperlipoproteinemic subjects homozygous for E2 displays a heterogeneity in receptor binding activity $(17,18)$, and that genotypic heterozygosity exists

\footnotetext{
${ }^{2}$ For the purposes of this discussion, type III hyperlipoproteinemia is used to indicate the lipid disorder characterized by hypercholesterolemia, hypertriglyceridemia, the E2/2 phenotype, the presence of $\beta$-VLDL, and the clinical sequelae, including xanthomatosis and/or vascular disease. Dysbetalipoproteinemia is used to refer to subjects with the E2/2 phenotype and $\beta$-VLDL, unaccompanied by hyperlipidemia and vascular disease.
}

within the E2/2 phenotype (24), it seemed important to understand the structural and receptor binding characteristics of the apo- $\mathrm{E}$ of hypo- and normocholesterolemic individuals with the E2/2 phenotype. In the present study, we will report evidence to show that apo-E2 from four hypo- and normocholesterolemic subjects appears to be structurally and functionally identical to the apo-E2 from severely hypercholesterolemic type III patients.

\section{METHODS}

Lipoprotein and apoprotein isolation and characterization. Lipoprotein density fractions were prepared from plasma by sequential ultracentrifugation (25). Protein was determined by the method of Lowry et al. (26). Total cholesterol and triglyceride levels were determined by using enzymatic procedures (Biodynamics/bmc, Boehringer Mannheim Corp., Indianapolis, IN). Phospholipid content of lipoproteins or apo-E-phospholipid complexes was determined from the phosphorus content (27). The presence of $\beta$-VLDL was ascertained by its electrophoretic migration on paper electrophoretograms (28).

The $d<1.006$ lipoproteins used for the preparation of apo-E were isolated from the plasma of subjects by ultracentrifugation for $16 \mathrm{~h}$ at $50,000 \mathrm{rpm}$ in a 60 -Ti rotor (Beckman Instruments, Inc., Spinco Div., Palo Alto, CA) and washed one time by recentrifugation. The $d<1.006$ lipoproteins were dialyzed against $0.01 \%$ EDTA (pH 7.4), lyophilized, and then delipidated with $2: 1$ (vol/vol) $\mathrm{CHCl}_{3}: \mathrm{CH}_{3} \mathrm{OH}$. The moist apoprotein pellet was solubilized in $6 \mathrm{M}$ guanidine, $0.1 \mathrm{M}$ Tris, and $0.01 \%$ EDTA (pH 7.4), and then reduced with $1 \% \beta$-mercaptoethanol and fractionated on a $2.5 \times 300-\mathrm{cm}$ column of either Sephadex G-200 or Sephacryl S-300 (Pharmacia Diagnostics, Div. of Pharmacia, Inc., Piscataway, NJ) equilibrated with $4 \mathrm{M}$ guanidine, $0.1 \mathrm{M}$ Tris, $0.01 \%$ EDTA, and $0.1 \% \beta$-mercaptoethanol (pH 7.4). The apo-E fractions were combined, dialyzed against $5 \mathrm{mM} \mathrm{NH}_{4} \mathrm{HCO}_{3}$, and lyophilized.

Analytical isoelectric focusing was performed on $6-\mathrm{cm}, 5 \%$ polyacrylamide gels containing $8 \mathrm{M}$ urea and $2 \%$ Pharmalyte (pH 4-6) (Pharmacia Fine Chemicals, Div. of Pharmacia, Inc.), as previously described (6). In some instances, the $d<1.006$ lipoproteins were chemically modified with $\beta$ mercaptoethylamine (cysteamine, Sigma Chemical Co., St. Louis, MO) by adding $1.0 \mathrm{mg}$ of cysteamine to $150 \mu \mathrm{g}$ of $d<1.006$ lipoprotein protein in $0.1 \mathrm{M} \mathrm{NH}_{4} \mathrm{HCO}_{3}$ and incubating the mixture for $4 \mathrm{~h}$ at $37^{\circ} \mathrm{C}$. The mixture was then lyophilized and delipidated before isoelectric focusing. Control samples were incubated in parallel with the modified samples and were reduced with $\beta$-mercaptoethanol before isoelectric focusing.

Amino acid and sequence analyses. Samples for amino acid analyses were hydrolyzed for $20 \mathrm{~h}$ at $110^{\circ} \mathrm{C}$ in $6 \mathrm{~N} \mathrm{HCl}$ in sealed, evacuated tubes. Samples were dried in vacuo at $40^{\circ} \mathrm{C}$, dissolved in $0.2 \mathrm{~N}$ sodium citrate, $\mathrm{pH} 2.2$, and analyzed on a Beckman $121 \mathrm{MB}$ Analyzer equipped with a Model 126 Data System (Beckman Instruments, Inc.). Lyophilized apo$\mathrm{E}$ for cyanogen bromide digestion was dissolved in $70 \%$ $\mathrm{HCOOH}$ at $5 \mathrm{mg} / \mathrm{ml}$ and digested with a 30 -fold excess (wt) wt) of CNBr (Pierce Chemical Co., Rockford, IL) for $24 \mathrm{~h}$ at room temperature. After lyophilization, the digests were dissolved in $2.5 \mathrm{ml}$ of $20 \% \mathrm{HCOOH}$ and fractionated on a $2.5 \times 190-\mathrm{cm}$ column of Sephadex G-50 (fine beads, Pharmacia Diagnostics) in $0.02 \mathrm{~N} \mathrm{HCl}$ at room temperature (flow 
rate, $18 \mathrm{ml} / \mathrm{h}$ ). Pooled fractions were lyophilized and redissolved in $0.5 \mathrm{ml}$ of $50 \%$ acetic acid for sequencing and amino acid analysis (24).

Peptides from the G-50 chromatography were subjected to sequence analysis, without further purification, in the presence of $2 \mathrm{mg}$ of polybrene (Sigma Chemical Co.) on a Beckman 890C Sequencer using a $0.1 \mathrm{M}$ Quadrol program (no. 122974) and standard Beckman reagents. Methods of analysis and criteria for identification of the phenylthiohydantoin amino acids by high performance liquid chromatography were as described $(6,24)$.

Fibroblast binding studies. Dimyristoylphosphatidylcholine (DMPC, Sigma Chemical Co.) vesicles were prepared by sonication (29). The apo-E was treated with cysteamine or $\beta$-mercaptoethanol before apo-E-DMPC complex formation. Cysteamine modification was performed by treating $200 \mu \mathrm{g}(1.0-1.5 \mathrm{mg}$ of protein $/ \mathrm{ml})$ of apo-E in $0.1 \mathrm{M}$ $\mathrm{NH}_{4} \mathrm{HCO}_{3}$ with $20 \mu \mathrm{l}$ of a cysteamine solution $(100 \mathrm{mg} / \mathrm{ml})$. The mixture was incubated overnight at room temperature or for $4 \mathrm{~h}$ at $37^{\circ} \mathrm{C}$. Unmodified samples were treated with $20 \mu \mathrm{l}$ of $\beta$-mercaptoethanol solution (1:10 dilution with $\mathrm{H}_{2} \mathrm{O}$ ) and incubated in parallel with the cysteamine samples.

The apo-E - DMPC complexes were prepared by incubating apo-E $(150 \mu \mathrm{g}$ of protein in $150-300 \mu \mathrm{l}$ of $0.1 \mathrm{M}$ $\left.\mathrm{NH}_{4} \mathrm{HCO}_{3}\right)$ with $56 \mu \mathrm{l}$ of DMPC $(10 \mathrm{mg} / \mathrm{ml})$ for $1 \mathrm{~h}$ at $25^{\circ} \mathrm{C}$ Complexes were isolated by ultracentrifugation at 55,000 rpm (SW 55 rotor) for $20 \mathrm{~h}$ at $15^{\circ} \mathrm{C}$ on a gradient of $\mathrm{KBr}$ $(d=1.006-1.21)(18)$. The ability of the apo-E - DMPC complexes to bind to the apo- $\mathrm{B}, \mathrm{E}$ receptors of cultured fibroblasts was determined in a $4^{\circ} \mathrm{C}$ competitive binding assay using ${ }^{125}$ I-LDL. The methodology used for the maintenance of the cells and the conditions of the assay have been described $(18,29)$.

\section{RESULTS}

Classification of subjects. Subjects were identified as part of a study on apo-E phenotypes in the German population (30), and six subjects were selected for more detailed analysis on the basis of their apo-E phenotypes and plasma cholesterol levels. All six subjects had the E2/2 homozygous phenotype as determined by onedimensional isoelectric focusing (Fig. 1). (Other selected data on these individuals are summarized in Table I.) Of the six subjects, two were classified as hypocholesterolemic, based on plasma cholesterol values below the 5 th percentile as defined by the Lipid Research Clinics Prevalence Study (31). Two subjects were normocholesterolemic, and two were hypercholesterolemic. The latter two had plasma cholesterol values that exceeded the 95th percentile (31). Of the hypercholesterolemic subjects, one (H.-O.K.) was clearly a type III hyperlipoproteinemic by all of the usual criteria. He had xanthomatosis and both coronary and peripheral vascular disease. The other subject (W.H.) had symptoms of type III hyperlipoproteinemia in some respects, i.e., a borderline VLDL-cholesterol/plasma triglyceride ratio and greatly elevated VLDL-cholesterol and VLDL-triglyceride levels. His relatively young age might have been a factor in his failure to display all of the clinical criteria of the dis-

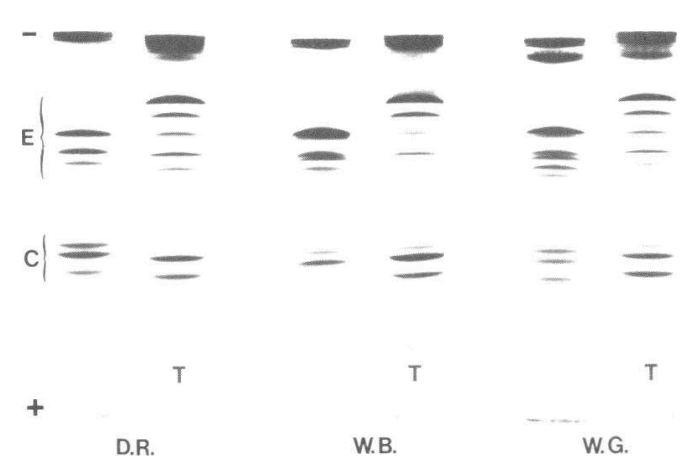

FIGURE 1 Isoelectric focusing on polyacrylamide gels $(\mathrm{pH}$ 4-6) of control and cysteamine-treated (T) VLDL from subjects with the E2/2 phenotype. The isoform pattern for the VLDL of D.R., who served as the source of apo-E2 reported previously (7), is shown for comparison. Brackets indicate the positions of the $\mathrm{E}$ isoforms and $\mathrm{C}$ apoproteins.

order. All of the subjects showed some evidence of dyslipoproteinemia (i.e., $\beta$-VLDL in the plasma), which has previously been demonstrated by other investigators to be prevalent within the $\mathrm{E} 2 / 2$ phenotype $(22,23)$. The subjects also had reduced LDL levels (as judged by LDL-cholesterol values); this is also consistent with previous findings for this phenotype (22).

Characterization of the apo-E2 from the six subjects. The mutant forms of apo-E2 that have thus far been described differ from apo-E3 by a single amino acid substitution of a cysteine residue for an arginine within the amino acid sequence $(7,24)$. ApoE3 contains a single residue of cysteine, whereas the apo-E2 mutants have two residues of cysteine per mole of protein. The number of cysteine residues per mole of apo-E can be rapidly determined by reacting the apo-E with the reagent cysteamine $(6,18,24)$. For each cysteine residue present, cysteamine treatment adds a single positive charge to the apo- $\mathrm{E}$, and by isoelectric focusing, the cysteamine-treated apo-E assumes a pI differing from the untreated apo-E by one unit of positive charge per cysteine. Thus, the mobility of cysteamine-treated apo-E3 is altered by one positive charge unit, and the mobility of cysteamine-treated apo-E2, which contains two cysteine residues, is altered by two positive charge units. As shown in Fig. 1 , for two of the subjects, the mobility of the apo-E2 was altered by two units of charge after cysteamine treatment. The same result was observed for the apoE2 of the other four subjects (data not shown). The cysteine content of the apo-E2 from three of the subjects was determined by direct sequence analysis, and these results confirmed that two residues of cysteine were present (see results described below).

Receptor binding of the apo-E2. The apo-E from 
TABLE I

Clinical Data on Subjects

\begin{tabular}{lcccccc}
\hline & E.G. & K.-H.M. & W.B. & W.G. & W.H. & H.-O.K. \\
\hline Sex & F & M & M & M & M & M \\
Age & 50 & 48 & 59 & 40 & 28 & 40 \\
Plasma cholesterol, $m g / d l$ & $138^{\circ}$ & $128^{\circ}$ & 187 & 181 & $274 \ddagger$ & $326 \ddagger$ \\
Plasma triglycerides, $m g / d l$ & 87 & 73 & 127 & 199 & $657 \ddagger$ & $522 \ddagger$ \\
Apo-E phenotype & $\mathrm{E} 2 / 2$ & $\mathrm{E} 2 / 2$ & $\mathrm{E} 2 / 2$ & $\mathrm{E} 2 / 2$ & $\mathrm{E} 2 / 2$ & $\mathrm{E} 2 / 2$ \\
$\beta$-VLDL & + & + & + & + & + & + \\
$d<1.006$ cholesterol, $m g / d l$ & 19 & 11 & 24 & 35 & 170 & 192 \\
$d<1.006$ triglycerides, $m g / d l$ & $\mathrm{ND}$ & 32 & 56 & 117 & 505 & 381 \\
$d=1.006-1.02$ cholesterol, $m g / d l$ & $\mathrm{ND}$ & 2 & 8 & 16 & 9 & 12 \\
$d=1.02-1.063$ cholesterol, $m g / d l$ & 51 & 41 & 77 & 63 & 19 & 33 \\
$d=1.063-1.21$ cholesterol, $m g / d l$ & 57 & 41 & 34 & 16 & 9 & 20 \\
VLDL-cholesterol/plasma triglycerides & 0.22 & 0.15 & 0.19 & 0.18 & 0.26 & 0.37 \\
\hline
\end{tabular}

- Plasma cholesterol values below the 5th percentile, Lipid Research Clinics Prevalence Study (31).

I Plasma cholesterol values above the 95th percentile, Lipid Research Clinics Prevalence Study (31).

ND, no data.

each subject was recombined with DMPC and tested for its ability to bind to the apo-B,E receptors of human fibroblasts. In addition, apo-E from each subject was treated with cysteamine, and its binding activity was compared with that of untreated apo-E. A representative competition experiment is shown in Fig. 2, and a summary of all binding experiments is presented in Table II. In all cases, the receptor binding of apo-E2 was severely defective compared with that of normalbinding apo-E3, which served as the control. Treatment of the apo- $\mathrm{E}$ of the subjects with cysteamine invariably resulted in a large increase in binding activity. Markedly defective binding ( $<2 \%$ of the binding activity of normal apo-E3) and a large increase in binding after cysteamine treatment (10- to 20-fold) have previously been demonstrated $(18,24)$ for the apo-E2 of a classical type III hyperlipoproteinemic subject (D.R.), whose apo-E2 amino acid sequence has been reported $(7,24)$.

The similarity in binding activity of the apo-E from the six subjects in this study and from subject D.R. of a previous study suggested a structural similarity in the apo-E of these subjects regardless of whether they were hypo-, normo-, or hypercholesterolemic. Recently, it has been established that there is a structural heterogeneity in the apo-E2 from type III hyperlipoproteinemic individuals of the E2/2 homozygous phenotype (24). This structural heterogeneity is due to differences in the location of one of the two cysteine residues that occur in apo-E2. The structural heterogeneity has been directly correlated with the func- tional heterogeneity, i.e., the severity of the binding defect, which has previously been documented in certain type III hyperlipoproteinemic subjects $(17,18)$. Therefore, it seemed necessary to determine, where possible, the location of the cysteine residues in the apo-E of the German subjects.

A partial sequence analysis of the cysteine-containing region of the apo-E2 was undertaken as previously described $(6,24)$. Limitations in the availability of sufficient apo-E for this type of analysis meant that apoE from only three of the six subjects (W.G., W.H., and H.-O.K.) could be studied. Column-purified apo-E was digested with $\mathrm{CNBr}$ and the peptides were separated by gel chromatography. Cysteine-containing peptides (Fig. 3) were subjected to amino acid and sequence analyses (Tables III and IV). Both the composition and sequence of the small peptide, CB4 (Fig. 3), were identical for the apo-E from subjects W.G., W.H., and H.O.K. Furthermore, the peptide was identical to the comparable peptide of the apo-E2 from other type III subjects and of the apo-E3 from subjects without type III hyperlipoproteinemia $(6,7,24)$. This peptide, corresponding to residues $109-125$ in the apo-E sequence (7), had the following structure: Glu-Asp-Val-Cys-GlyArg-Leu-Val-Gln-Tyr-Arg-Gly-Glu-Val-Gln-Ala-Met. It has previously been shown that the cysteine residue of this peptide (position 112 in the sequence) is not involved in the interaction of apo-E3 with receptors (18) and, as could be expected, there was no effect on binding when this cysteine residue was replaced by arginine, as occurs in apo-E4 $(6,18,24)$. 

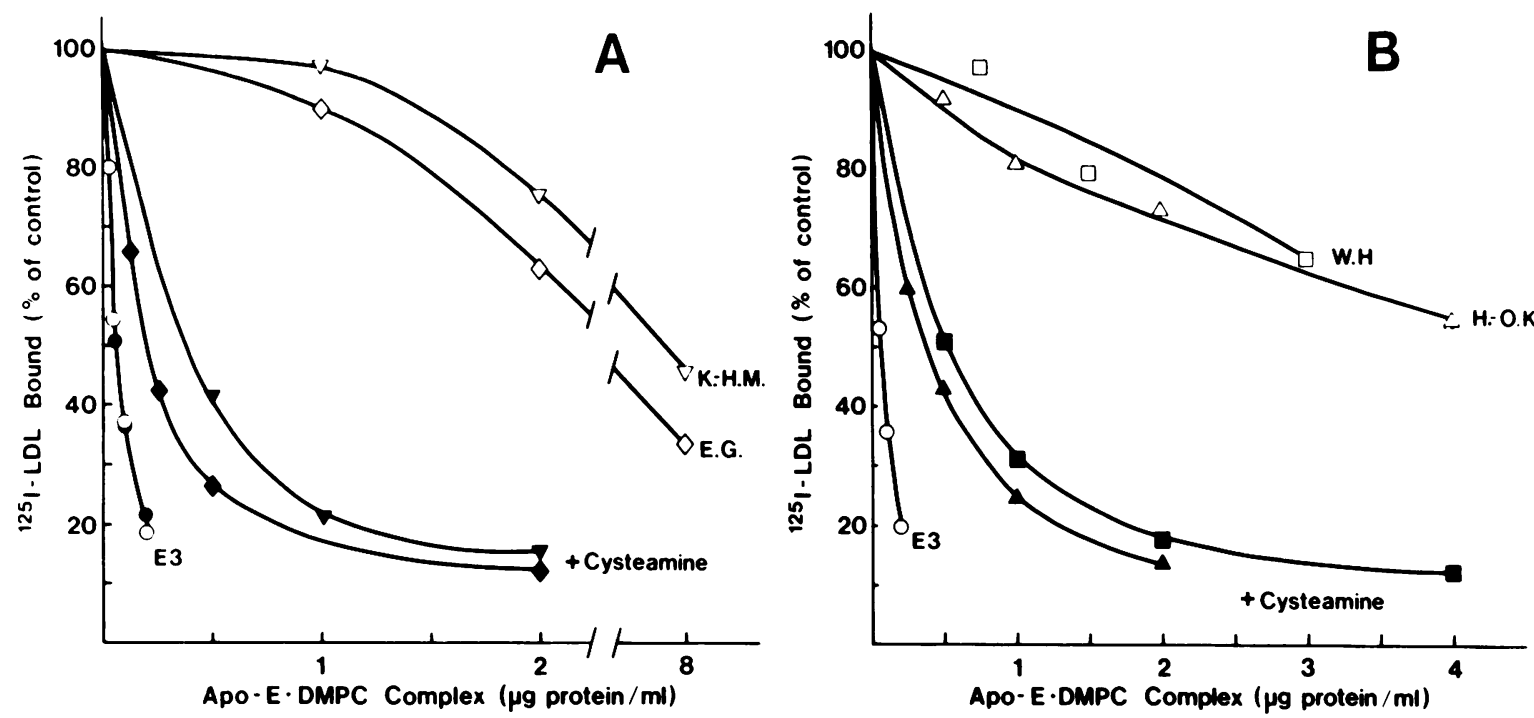

Figure 2 Ability of apo-E2 - DMPC from hypolipidemic (A; E.G. and K.-H.M.) and hyperlipidemic (B; W.H. and H.-O.K.) subjects to compete with human ${ }^{125}$ I-LDL for binding to receptors on cultured human fibroblasts. The binding activity of the apo-E2 $(\nabla, \diamond, \square, \Delta)$ was markedly enhanced after cysteamine treatment of the apo-E2 $(\boldsymbol{\nabla}, \boldsymbol{\nabla}, \boldsymbol{\nabla}, \mathbf{\Delta})$. Also shown for comparison is normal apo-E3 - DMPC with $(O)$ or without $(\bullet)$ treatment with cysteamine. The fibroblast monolayers were incubated for $48 \mathrm{~h}$ before the experiment with Dulbecco's modified Eagle's medium containing 10\% human lipoprotein-deficient medium. Then $1 \mathrm{ml}$ of Dulbecco's modified Eagle's medium containing $0.25 \mathrm{mM}$ Hepes, $\mathrm{pH} 7.4$, was added to the cells with 2 $\mu \mathrm{g}$ of ${ }^{125} \mathrm{I}-\mathrm{L}$.DI, and the indicated concentrations of protein $\cdot$ phospholipid complexes. After a $2-h$ incubation on ice, the cells on the $35-\mathrm{mm}$ petri dishes were extensively washed, and the amount of ${ }^{125} \mathrm{I}-\mathrm{LDL}$ that bound to the cells was determined. Both panels are from the same experiment and are plotted separately for clarity. The $100 \%$ control value with no added apoE.DMPC complexes was $45 \mathrm{ng}$ of ${ }^{125} \mathrm{I}$-L.DL protein bound $/ \mathrm{mg}$ of cellular protein. Each point is the average of duplicate dishes.

The large, cysteine-containing peptide, CB5 (Fig. 3), from subjects W.G., W.H., and H.-O.K. (Table III) was not significantly different from the comparable peptide of subject D.R. (7). Partial sequence analyses of the CB5 of W.G., W.H., and H.-O.K. revealed that the cysteine residue occurred at cycle 33 (residue 158) in the apo-E sequence. This is the same site at which cysteine occurred in the apo-E2 of subject D.R. (7). It is this cysteine residue that has been shown to have a profound effect on the receptor binding ability of apo-E2 $(18,24)$. (Table IV compares data from W.H. and W.G.)

\section{DISCUSSION}

The structural and receptor binding studies on the apoE2 from hypo-, normo-, and hypercholesterolemic E2/ 2 subjects indicated that the apo- $\mathrm{E}$ from these individuals was identical. A partial amino acid sequence analysis of the apo-E2 from three of these E2 homozygous subjects revealed that the cysteine-containing segment of the polypeptide chain (corresponding to residues 109-177) was also identical to that of the apo-
E from the type III hyperlipoproteinemic subject D.R. (7). This is the region of the apo-E molecule in which all of the known amino acid substitutions occur (24) and is also the region of the molecule that has been implicated in receptor binding (32). A cysteine for arginine substitution was evident in the apo-E2 of subjects H.-O.K., W.H., and W.G. in this critical region of the molecule (residue 158), as well as in that of subject D.R. (7). Furthermore, the apo-E2 from all of these subjects was severely defective in receptor binding activity $(<2 \%$ of the binding activity of normal apo-E3) and demonstrated a marked increase in binding after cysteamine treatment.

Recently, the structure of the apo-E2 from an additional type III hyperlipoproteinemic subject (W.M.) was shown to differ from normal apo-E3 by a cysteine/ arginine interchange at residue 145 (24). This mutant form of apo-E2 was much less defective than the other mutant apo-E2 in respect to binding activity (demonstrating $\sim 50 \%$ of the activity of normal apo-E). This along with other evidence indicates that binding heterogeneity correlates with structural heterogeneity $(24,32)$. Therefore, the similarity in binding activity 
TABLE II

Summary of Receptor Binding Activity of Apo-E D DMPC from E2/2 Homozygous Subjects

\begin{tabular}{|c|c|c|c|}
\hline \multirow[b]{2}{*}{ Subject } & \multicolumn{2}{|c|}{$\begin{array}{l}\text { Concentration of apo- } \\
\text { E. DMPC at which } \\
50 \%{ }^{125} \text { I-LDL was } \\
\text { displaced from } \\
\text { fibroblasts }\end{array}$} & \multirow{2}{*}{$\begin{array}{l}\text { Cysteamine } \\
\text { activation } \\
\text { (control/treated) }\end{array}$} \\
\hline & Control & $\begin{array}{l}\text { Cysteamine- } \\
\text { treated }\end{array}$ & \\
\hline & \multicolumn{2}{|c|}{$\mu g$ protein $/ m l$} & \\
\hline "Normal" E3/3 & 0.057 & 0.051 & 1.1 \\
\hline \multicolumn{4}{|c|}{ Dysbetalipoproteinemic E2/2 } \\
\hline E.G. & 3.5 & 0.21 & 16.7 \\
\hline K.-H.M. & 6.2 & 0.37 & 16.7 \\
\hline \multicolumn{4}{|c|}{ Normocholesterolemic } \\
\hline W.B. & 5.0 & 0.35 & 14.3 \\
\hline W.G. & 4.6 & 0.23 & 19.9 \\
\hline \multicolumn{4}{|c|}{ Hypercholesterolemic } \\
\hline W.H. & 5.5 & 0.44 & 12.5 \\
\hline H.-O.K. & 5.0 & 0.38 & 13.2 \\
\hline
\end{tabular}

- Compiled from competitive binding experiments as described in the legend to Fig. 2. A logit-logit plot of binding data was used to determine the $50 \%$ competition point.

and the presence of two residues of cysteine (as determined by partial sequence analyses or cysteamine treatment) in the apo-E of all six E2/2 subjects in the present study suggest that these proteins were structurally identical. One must conclude that the presence of receptor-defective apo-E2, as observed in these

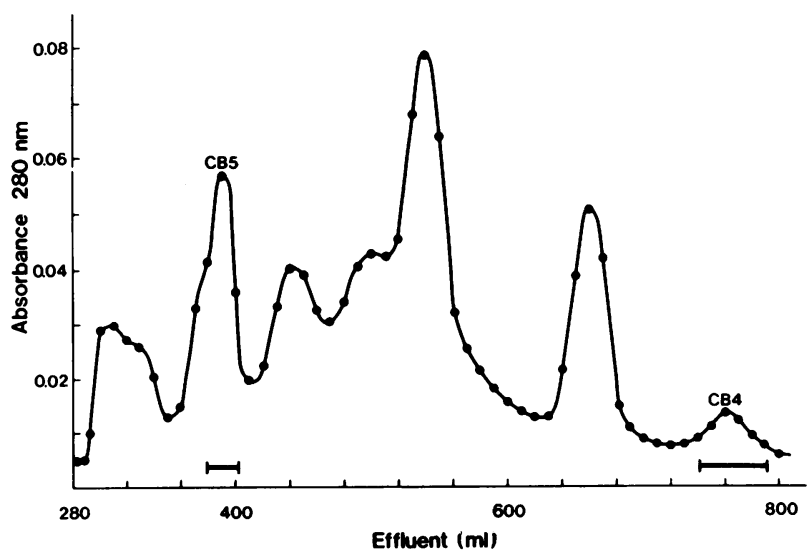

Ficiurl: 3 Sephadex G-50 chromatography of the CNBr digest of $6.5 \mathrm{mg}$ of apo-E2 from subject W.H. Peptide fractions CB5 and CB4 were pooled as indicated by the horizontal bars
TABLE III

Amino Acid Compositions of the Cysteine-containing $\mathrm{CNBr}$ Peptides of Apo-E $2^{\circ}$

\begin{tabular}{|c|c|c|c|c|c|c|}
\hline & \multicolumn{2}{|c|}{ w.G. } & \multicolumn{2}{|c|}{ W.H. } & \multicolumn{2}{|c|}{ H.-O.K. } \\
\hline & $\mathrm{CB} 4$ & CB5 & CB4 & CB5 & $\mathrm{CB} 4$ & CB5 \\
\hline Asp & $1.1(1)$ & 3.7 & $1.0(1)$ & 3.3 & $1.1(1)$ & 3.5 \\
\hline Thr & 0.2 & 2.3 & 0.2 & 2.1 & 0.2 & 2.2 \\
\hline Ser & 0.3 & 3.8 & 0.3 & 3.6 & 0.3 & 3.8 \\
\hline Glu & $4.4(4)$ & 15.8 & $4.2(4)$ & 16.1 & $4.5(4)$ & 15.6 \\
\hline Pro & 0.2 & 2.4 & - & 2.2 & - & 2.2 \\
\hline Gly & $1.9(2)$ & 8.5 & $1.9(2)$ & 8.8 & $2.0(2)$ & 8.7 \\
\hline Ala & $1.2(1)$ & 11.8 & $1.1(1)$ & 12.7 & $1.1(1)$ & 12.4 \\
\hline Cys! & $0.8(1)$ & 1.0 & $0.8(1)$ & 1.0 & $0.7(1)$ & 1.2 \\
\hline Val & $2.8(3)$ & 5.5 & $2.9(3)$ & 6.0 & $3.1(3)$ & 5.7 \\
\hline Met $\S$ & $0.3(1)$ & 0.3 & $0.4(1)$ & 0.3 & $0.3(1)$ & 0.4 \\
\hline Ile & 0.1 & 1.0 & - & 1.0 & - & 0.9 \\
\hline Leu & $1.5(1)$ & 14.5 & $1.2(1)$ & 14.7 & $1.4(1)$ & 14.7 \\
\hline Tyr & $0.8(1)$ & 0.9 & $0.8(1)$ & 1.0 & $0.7(1)$ & 1.0 \\
\hline Phe & 0.1 & - & - & - & - & - \\
\hline Lys & 0.2 & 3.3 & 0.1 & 3.1 & 0.1 & 3.2 \\
\hline His & - & 1.0 & - & 1.0 & - & 1.0 \\
\hline Arg & $2.0(2)$ & 14.5 & $1.8(2)$ & 15.4 & $1.9(2)$ & 15.0 \\
\hline
\end{tabular}

- Compositions are given in residues per mole; numbers in parentheses for CB4 are residues determined from sequence.

t Determined as cysteic acid after performic acid oxidation.

$\S$ Determined as homoserine lactone

hypo-, normo-, and hypercholesterolemic E2/2 subjects, may not be sufficient for the expression of type III hyperlipoproteinemia.

The development of severe type III hyperlipoproteinemia (with hypercholesterolemia and hypertriglyceridemia) may require the existence of genetic or metabolic abnormalities in addition to the presence of a functionally defective form of apo-E. One is struck by the variety of environmental and hormonal factors that exacerbate or modulate the severity of the expression of the type III disorder, including age, sex, diet, obesity, hypothyroidism, and diabetes (21). It has recently been shown that the $\beta$-VLDL of type III hyperlipoproteinemic subjects actually represent two distinct lipoprotein classes, one of intestinal origin (chylomicron remnants) and a second apparently of hepatic origin (cholesterol-enriched VLDL) (11). Thus, the abnormalities of type III hyperlipoproteinemia may result from factors that impair the catabolism (hepatic uptake) of chylomicron remnants or that increase the production of hepatic VLDL, or both.

It is easy to envision how subjects with defective apo-E might develop hyperlipoproteinemia. The removal of chylomicron remnants from the plasma is carried out by the liver via receptor-mediated endocytosis (12-16), a process that appears to be mediated 
TABLE IV

Partial Sequence of Peptide CB5 of Apo-E2

from a Hypercholesterolemic (W.H.) and

Normocholesterolemic (W.G.) Subject ${ }^{\circ}$

\begin{tabular}{|c|c|c|c|c|}
\hline $\begin{array}{l}\text { Residue } \\
\text { numbert }\end{array}$ & $\begin{array}{c}\text { Cycle } \\
\text { number }\end{array}$ & $\begin{array}{l}\text { Amino acid } \\
\text { identified }\end{array}$ & $\begin{array}{l}\text { Subject } \\
\text { W.H. }\end{array}$ & $\begin{array}{c}\text { Subject } \\
\text { w.G. }\end{array}$ \\
\hline & & & \multicolumn{2}{|c|}{ nmol } \\
\hline- & 0 & - & 57 & 81 \\
\hline 126 & 1 & Leu & 19.1 & 19.4 \\
\hline 127 & 2 & Gly & 26.2 & 26.7 \\
\hline 128 & 3 & Gln & 11.6 & 6.9 \\
\hline 129 & 4 & Ser & 9.7 & 11.9 \\
\hline 130 & 5 & Thr & 10.8 & 13.3 \\
\hline 131 & 6 & Glu & 25.0 & 10.9 \\
\hline 132 & 7 & Glu & 25.8 & 13.4 \\
\hline 133 & 8 & Leu & 25.7 & 21.0 \\
\hline 134 & 9 & Arg & 6.7 & 2.4 \\
\hline 135 & 10 & $\mathrm{Val}$ & 30.2 & 23.5 \\
\hline 136 & 11 & Arg & 6.6 & 4.3 \\
\hline 137 & 12 & Leu & 23.6 & 18.1 \\
\hline 138 & 13 & Ala & 27.6 & 20.6 \\
\hline 139 & 14 & Ser & 7.5 & 6.0 \\
\hline 140 & 15 & His & 3.2 & 2.0 \\
\hline 141 & 16 & Leu & 16.8 & 17.1 \\
\hline 142 & 17 & Arg & 6.5 & 2.1 \\
\hline 143 & 18 & Lys & 2.9 & 3.0 \\
\hline 144 & 19 & Leu & 18.4 & 16.5 \\
\hline 145 & 20 & Arg & 5.0 & 2.2 \\
\hline 146 & 21 & Lys & 2.4 & 2.2 \\
\hline 147 & 22 & Arg & 6.1 & 2.6 \\
\hline 148 & 23 & Leu & 17.7 & 14.9 \\
\hline 149 & 24 & Leu & 17.9 & 17.7 \\
\hline 150 & 25 & Arg & 4.5 & 2.1 \\
\hline 151 & 26 & Asp & 6.6 & 3.2 \\
\hline 152 & 27 & Ala & 19.6 & 13.8 \\
\hline 153 & 28 & Asp & 6.2 & 3.0 \\
\hline 154 & 29 & Asp & 8.6 & 2.8 \\
\hline 155 & 30 & Leu & 15.3 & 10.9 \\
\hline 156 & 31 & Gln & 5.1 & 3.2 \\
\hline 157 & 32 & Lys & 2.7 & 1.7 \\
\hline 158 & 33 & Cys & 1.8 & 1.7 \\
\hline 159 & 34 & Leu & 11.1 & 9.5 \\
\hline 160 & 35 & Ala & 13.4 & 9.9 \\
\hline 161 & 36 & Val & 11.2 & 7.6 \\
\hline 162 & 37 & Tyr & 6.3 & 3.1 \\
\hline 163 & 38 & Gln & 3.6 & 2.4 \\
\hline 164 & 39 & Ala & 10.9 & 7.7 \\
\hline 165 & 40 & Gly & 6.4 & 4.9 \\
\hline 166 & 41 & Ala & 10.5 & 8.1 \\
\hline 167 & 42 & Arg & 2.3 & 1.3 \\
\hline 168 & 43 & Glu & 7.4 & 3.1 \\
\hline 169 & 44 & Gly & 7.5 & 5.3 \\
\hline 170 & 45 & Ala & 8.8 & 6.2 \\
\hline 171 & 46 & Glu & 6.2 & 2.9 \\
\hline 172 & 47 & Arg & 1.9 & 0.8 \\
\hline 173 & 48 & Gly & 7.3 & 4.9 \\
\hline 174 & 49 & Leu & 4.9 & 4.1 \\
\hline 175 & 50 & Ser & 1.7 & $>0$ \\
\hline 176 & 51 & Ala & 6.7 & 4.9 \\
\hline 177 & 52 & Ile & 3.9 & 2.7 \\
\hline
\end{tabular}

- The same 52-residue sequence was also obtained for CB5 of apoE2 from the type III hyperlipoproteinemic subject H.-O.K. (data not shown). The entire sequence of apo-E2 from the type III hyperlipoproteinemic subject D.R. has been reported (7).

$\ddagger$ From apo-E2 of subject D.R. $(6,7,24)$. primarily or exclusively by apo-E. The presence of a mutant form of apo-E that is deficient in receptor binding capabilities would certainly disrupt this process. However, it is more difficult to understand why hyperlipidemia does not develop in all subjects in which an abnormal form of apo-E exists. In the present study, the apo-E of the hypo- and normocholesterolemic subjects was just as defective in respect to receptor binding as that of the hypercholesterolemic individuals.

It is reasonable to speculate that the chylomicron remnants of normolipidemic E2 homozygous subjects may be cleared by some other mechanism. It is possible that under these conditions the apo-B in chylomicron remnants of these subjects mediates the uptake of the remnants by the hepatic lipoprotein receptors. The efficiency of this process would depend on the level of the expression of the hepatic apo- $\mathrm{B}, \mathrm{E}$ receptors. The expression of these receptors would be critical in determining the extent of the lipoprotein abnormality in subjects with defective apo-E. Furthermore, it should be recalled that, even though all six of these subjects had severely defective apo-E, the apo-E did display a low level of binding activity, which may account for some clearance of lipoproteins by either the apo- $\mathrm{B}, \mathrm{E}$ or apo-E receptors.

These two distinct hepatic lipoprotein receptors, the apo-B,E (LDL) receptor and the apo-E receptor, are the primary lipoprotein receptors in the livers of man and certain animals. They are both capable of interacting with chylomicron remnants in vitro $(15,16)$. The hepatic apo-E receptor is relatively refractory to changes in expression that are brought about by metabolic perturbations $(15,16)$. However, the expression of hepatic apo-B,E receptors is rapidly and efficiently modulated by diet, drugs, hormones, and varying plasma concentrations of lipoproteins and bile acids (14-16, 33). In addition, the expression of the hepatic apo-B,E receptor is age-dependent. Young immature animals reveal very high levels of hepatic apo-B,E receptors, whereas adult animals express very low levels of hepatic apo-B,E receptors. (The hepatic apo-E receptors are not affected by age). Adult human livers, like those of adult animals, reveal very low levels of apo-B,E receptors (16). This is significant when considering that the manifestations of type III hyperlipoproteinemia are very age-dependent: they rarely, if ever, occur before adulthood (21). It is reasonable to speculate that the hyperlipidemia may result at this time because of the inability of the lower level of hepatic apo-B,E receptors to clear the chylomicron remnants.

The sensitivity of this lipid disorder to diet, drugs, and hormonal balance further suggests a role for the expression, or lack of expression, of the hepatic apo- 
B,E receptors. For example, type III hyperlipoproteinemia in women most of ten occurs after menopause (21), and in these individuals the disorder is particularly responsive to estrogen therapy (34-36). The induction of hepatic apo-B,E receptors in animals given estrogen, though at nonpharmacologic doses, has previously been reported $(37,38)$. The role of hypothyroidism in the exacerbation of type III hyperlipoproteinemia (21) and the effects of thyroid hormone on receptor-mediated lipoprotein catabolism (39) further suggest that a modulation of hepatic apo-B,E receptors may be involved in the type III disorder. Those subjects homozygous for the E2/2 phenotype who do not have hyperlipoproteinemia may be capable of maintaining high levels of hepatic apo- $\mathrm{B}, \mathrm{E}$ receptor activity and are therefore able to clear certain lipoproteins from the plasma (e.g., chylomicron remnants, which contain the defective apo-E)

The development of type III hyperlipoproteinemia may also result, at least in part, from an overproduction of hepatic cholesterol and/or hepatic VLDL. A primary cause for the overproduction of hepatic VLDL could be the impaired clearance of chylomicron remnants, which results in a deficiency in the delivery of cholesterol to the liver. As a result, hepatic cholesterol biosynthesis, and possibly hepatic VLDL production, could be stimulated. These newly secreted hepatic VLDL, either because of the presence of defective apo-E or because of an abnormal particle composition, may not be metabolized normally and thus could accumulate in the plasma. Furthermore, there may be several secondary causes for hepatic overproduction of VLDL and cholesterol. Various conditions that are known to exacerbate type III hyperlipoproteinemia, e.g., obesity, obesity with hypothyroidism, diabetes and age, have been shown to stimulate hepatic synthesis of VLDL and/or cholesterol (for review, see ref. 40). In addition, Utermann et al. (2) and Hazzard et al. (23) have presented compelling evidence from kindred studies that the development of type III hyperlipoproteinemia is expressed in some E2 homozygous subjects in combination with a second heritable hyperlipidemia, such as familial combined hyperlipoproteinemia. The defect in those individuals with familial combined hyperlipoproteinemia may well be a hepatic overproduction of cholesterol and VLDL (41).

It is clear that the expression of type III hyperlipoproteinemia is complex. The description of the abnormalities in the apo-E2 of these subjects provides a basis for understanding this lipoprotein disorder; however, other factors clearly interact to modulate its expression. The considerations discussed represent testable hypotheses.

\section{ACKNOWLEDGMENTS}

We thank Reed Harris, Kay Arnold, David Begert, and Jana Seymour for excellent technical assistance. We also thank Russell Levine for editorial assistance and Gwen Watson for graphic arts.

\section{REFERENCES}

1. Utermann, G., M. Hees, and A. Steinmetz. 1977. Poly morphism of apolipoprotein $\mathrm{E}$ and occurrence of dysbetalipoproteinaemia in man. Nature (Lond.). 269: 604607.

2. Utermann, G., K. H. Vogelberg, A. Steinmetz, W Schoenborn, N. Pruin, M. Jaeschke, M. Hees, and H. Canzler. 1979. Polymorphism of apolipoprotein E. II. Genetics of hyperlipoproteinemia type III. Clin. Genet. 15: $37-62$

3. Utermann, G., U. Langenbeck, U. Beisiegel, and W. Weber. 1980. Genetics of the apolipoprotein E system in man. Am. J. Hum. Genet. 32: 339-347.

4. Zannis, V. I., and J. L. Breslow. 1981. Human very low density lipoprotein apolipoprotein $\mathrm{E}$ isoprotein polymorphism is explained by genetic variation and posttranslational modification. Biochemistry. 20: 1033-1041.

5. Zannis, V. I., P. W. Just, and J. L. Breslow. 1981. Human apolipoprotein $\mathrm{E}$ isoprotein subclasses are genetically determined. Am. J. Hum. Genet. 33: 11-24.

6. Weisgraber, K. H., S. C. Rall, Jr., and R. W. Mahley. 1981. Human $\mathrm{E}$ apoprotein heterogeneity. Cysteine-arginine interchanges in the amino acid sequence of the apo-E isoforms. J. Biol. Chem. 256: 9077-9083.

7. Rall, S. C., Jr., K. H. Weisgraber, and R. W. Mahley. 1982. Human apolipoprotein $\mathrm{E}$. The complete amino acid sequence. J. Biol. Chem. 257: 4171-4178.

8. Utermann, G., M. Jaeschke, and J. Menzel. 1975. Familial hyperlipoproteinemia type III: deficiency of a specific apolipoprotein (apo-E-III) in the very-low-density lipoproteins. FEBS (Fed. Eur. Biochem. Soc.) Lett. 56: 352-355

9. Pagnan, A., R. J. Havel, J. P. Kane, and L. Kotite. 1977. Characterization of human very low density lipoproteins containing two electrophoretic populations: double prebeta lipoproteinemia and primary dysbetalipoproteinemia. J. Lipid Res. 18: 613-622.

10. Zannis, V. I., and J. L. Breslow. 1980. Characterization of a unique human apolipoprotein $\mathrm{E}$ variant associated with type III hyperlipoproteinemia. J. Biol. Chem. 255: 1759-1762

11. Fainaru, M., R. W. Mahley, R. L. Hamilton, and T. L. Innerarity. 1982. Structural and metabolic heterogeneity of $\beta$-very low density lipoproteins from cholesterol-fed dogs and from humans with Type III hyperlipoproteinemia. J. Lipid Res. 23: 702-714.

12. Sherrill, B. C., T. L. Innerarity, and R. W. Mahley. 1980 Rapid hepatic clearance of the canine lipoproteins containing only the $\mathrm{E}$ apoprotein by a high affinity receptor Identity with the chylomicron remnant transport process. J. Biol. Chem. 255: 1804-1807.

13. Havel, R. J., Y.-S. Chao, E. E. Windler, L. Kotite, and L. S. S. Guo. 1980. Isoprotein specificity in the hepatic uptake of apolipoprotein $\mathrm{E}$ and the pathogenesis of $\mathrm{fa}$ milial dysbetalipoproteinemia. Proc. Natl. Acad. Sci. USA. 77: 4349-4353.

14. Brown, M. S., P. T. Kovanen, and J. L. Goldstein. 1981 
Regulation of plasma cholesterol by lipoprotein receptors. Science (Wash. DC). 212: 628-635.

15. Hui, D. Y., T. L. Innerarity, and R. W. Mahley. 1981 Lipoprotein binding to canine hepatic membranes: metabolically distinct apo-E and apo-B,E receptors. J. Biol. Chem. 256: 5646-565.5.

16. Mahley, R. W., D. Y. Hui, T. L. Innerarity, and K. H Weisgraber. 1981. Two independent lipoprotein receptors on hepatic membranes of dog, swine, and man. Apo$\mathrm{B}, \mathrm{E}$ and apo-E receptors. J. Clin. Invest 68: 1197-1206

17. Schneider, W. J., P. T. Kovanen, M. S. Brown, J. L. Goldstein, G. Utermann, W. Weber, R. J. Havel, L. Ko tite, J. P. Kane, T. L. Innerarity, and R. W. Mahley. 1981. Familial dysbetalipoproteinemia. Abnormal binding of mutant apoprotein $\mathrm{E}$ to low density lipoprotein receptors of human fibroblasts and membranes from liver and adrenal of rats, rabbits, and cows. J. Clin. Invest. 68: 1075-1085.

18. Weisgraber, K. H., T. L. Innerarity, and R. W. Mahley 1982. Abnormal lipoprotein receptor-binding activity of the human $\mathrm{E}$ apoprotein due to cysteine-arginine interchange at a single site. J. Biol. Chem. 257: 2518-2521.

19. Gregg, R. E., L. A. Zech, E. J. Schaefer, and H. B Brewer, Jr. 1981. Type III hyperlipoproteinemia: defective metabolism of an abnormal apolipoprotein $\mathrm{E}$ Science (Wash. DC). 211: 584-586.

20. Hazzard, W. R., T. F. O'Donnell, and Y. L. Lee. 1975 Broad-beta disease (type III hyperlipoproteinemia) in a large kindred. Evidence for a monogenic mechanism Ann. Intern. Med. 82: 141-149.

21. Fredrickson, D. S., J. L. Goldstein, and M. S. Brown 1978. The familial hyperlipoproteinemias. In The Metabolic Basis of Inherited Disease. J. B. Stanbury, J. B Wyngaarden, and D. S. Fredrickson, editors. 4th edition). McGraw-Hill, Inc., New York. 604-655.

22. Utermann, G., N. Pruin, and A. Steinmetz. 1979. Polymorphism of apolipoprotein E. III. Effect of a single polymorphic gene locus on plasma lipid levels in man. Clin. Genet. 15: 63-72.

23. Hazzard, W. R., G. R. Warnick, G. Utermann, and J. J. Albers. 1981. Genetic transmission of isoapolipoprotein $\mathrm{E}$ phenoty pes in a large kindred: relationship to dysbetalipoproteinemia and hyperlipidemia. Metab. Clin. Exp. 30: 79-88.

24. Rall, S. C.. Jr., K. H. Weisgraber, T. L. Innerarity, and R. W. Mahley. 1982. Structural basis for receptor binding heterogeneity of apolipoprotein $\mathrm{E}$ from type III hyperlipoproteinemic subjects. Proc. Natl. Acad. Sci. USA. 79: $4696-4700$.

25. Havel, R. J., H. A. Eder, and J. H. Bragdon. 1955. Distribution and chemical composition of ultracentrifugally separated lipoproteins in human serum. J. Clin. Invest. 34: $1345-1353$.

26. Lowry, (). H., N. J. Rosebrough, A. L. Farr, and R. J Randall. 1951. Protein measurement with the Folin phenol reagent. J. Biol. Chem. 193: 265-275.

27. Bartlett, G. R. 1959. Phosphorus assay in column chromatography. J. Biol. Chem. 234: 466-468.

28. Hatch, F. T., and R. S. Lees. 1968. Practical methods for plasma lipoprotein analysis. Adv. Lipid Res. 6: 1-68.
29. Innerarity, T. L., R. E. Pitas, and R. W. Mahley. 1979. Binding of arginine-rich (E) apoprotein after recombination with phospholipid vesicles to the low density lipoprotein receptors of fibroblasts. J. Biol. Chem. 254: $4186-4190$

30. Menzel, H. J., R. G. Kladetzky, and G. Assmann. 1983. Apolipoprotein $\mathrm{E}$ polymorphism and coronary artery disease. Arteriosclerosis. In press.

31. Heiss, G., 1. Mebane, and I. Tamir. 1980. The Lipid Research Clinics Population Studies Data Book. I. The Prevalence Study. (NIH Publication No. 80-1527), Bethesda, MD. 1-136.

32. Mahley, R. W., S. C. Rall, Jr., T. L. Innerarity, and K. H. Weisgraber. 1983. Apolipoprotein E and cholesterol metabolism. In Atherosclerosis VI. In press.

33. Angelin, B., C. Raviola, T. L. Innerarity, and R. W. Mahley. 1983. Regulation of hepatic lipoprotein receptors in the dog. Rapid regulation of apolipoprotein $\mathrm{B}, \mathrm{E}$ receptors, but not of apolipoprotein $\mathrm{E}$ receptors, by intestinal lipoproteins and bile acids. J. Clin. Invest. 71: $816-8: 31$

34. Chait, A., J. D. Brunzell, J. J. Albers, and W. R. Hazzard. 1977. Type-III hyperlipoproteinaemia ("remnant removal disease"). Insight into the pathogenic mechanism. Lancet. I: 1176-1178

35. Kushwaha, R. S., W. R. Hazzard, C. Gagne, A. Chait and J. J. Albers. 1977. Type III hyperlipoproteinemia: paradoxical hypolipidemic response to estrogen. Ann. Intern. Med. 87: 517-525.

36. Falko, J. M., G. Schonfeld, J. L. Witzum, J. Kolar, and S. W. Weidman. 1979. Effects of estrogen therapy on apolipoprotein $\mathrm{E}$ in type III hyperlipoproteinemia. Me tab. Clin. Exp. 28: 1171-1177.

37. Windler, E. E., P. T. Kovanen, Y.-S. Chao, M. S. Brown R. J. Havel, and J. L. Goldstein. 1980. The estradiolstimulated lipoprotein receptor of rat liver. A binding site that mediates the uptake of rat lipoproteins containing apoproteins B and E. J. Biol. Chem. 255: 1046410471 .

38. Kovanen, P. T., M. S. Brown, and J. L. Goldstein. 1979 Increased binding of low density lipoprotein to liver membranes from rats treated with 17 alpha-ethinyl estradiol. J. Biol. Chem. 254: 11367-11373.

39. Thompson, G. R., A. K. Soutar, F. A. Spengel, A. Jadhav S. J. P. Gavigan, and N. B. Myant. 1981. Defects of receptor-mediated low density lipoprotein catabolism in homozygous familial hypercholesterolemia and hypothyroidism in vivo. Proc. Natl. Acad. Sci. USA. 78: 25912595.

40. Grundy, S. M. 1982. Hypertriglyceridemia: mechanisms, clinical significance, and treatment. In The Medical Clinics of North America: Lipid Disorders. R. J Havel, editor. W. B. Saunders Company, Philadelphia. 66: 519-535.

41. Chait, A., J. J. Albers, and J. D. Brunzell. 1980. Very low density lipoprotein overproduction in genetic forms of hypertriglyceridaemia. Eur. J. Clin. Invest. 10: 1722. 